\title{
The Sustainable Management of Metals: An Analysis of Global Research
}

\author{
José A. Aznar-Sánchez *®i), Juan F. Velasco-Muñoz®) José J. García-Gómez \\ and María J. López-Serrano
}

Department of Economics and Business, Research Centre CAESCG and CIAIMBITAL, University of Almería, 04120 Almería, Spain; jfvelasco@ual.es (J.F.V.-M.); josejgg@ual.es (J.J.G.-G.); mls377@inlumine.ual.es (M.J.L.-S.)

* Correspondence: jaznar@ual.es; Tel.: +34-950-015-192

Received: 12 September 2018; Accepted: 3 October 2018; Published: 8 October 2018

\begin{abstract}
The objective of this study was to analyze research trends in the field of sustainable management of metals on a global level between 1993 and 2017. To do so, a bibliometric analysis was carried out on a total of 6967 articles. The results revealed the growing interest in this research field, particularly over the last five year-period during which $63 \%$ of all articles were published. The three journals in which most articles had been published were the Journal of Cleaner Production, ACS Sustainable Chemistry and Engineering, and Chemsuschem. The countries that published the most articles were China, the United States, India, Germany, and the United Kingdom. A sizeable network of collaboration has been established between countries for the joint publication of studies. The main lines of research have been focused on metal decontamination in water and soil, waste management oriented towards reuse and recycling, and the innovation of processes for cleaner and more efficient production. The results revealed the need for comprehensive studies that integrate different disciplines within the same analytical framework, and to promote research that contributes to the different dimensions of sustainability (environmental, economic, and social).
\end{abstract}

Keywords: scientific research; metal; sustainability; bibliometric analysis; Scopus

\section{Introduction}

The sustainable management of metals has become a relevant research field over the last few decades. The "Sustainability" concept was born in the 1990s. It was defined by the Brundtland Commission as follows: "Development which meets the needs of the present, without compromising the ability of future generations to meet their own needs" [1]. If the term is applied to metals, it could be defined as "the management over the whole metal life, able to meet current demands without risking future ones and setting limits to environmental, economic and social impacts". Some relevant works on the sustainable management of metal are those produced by Nath and Stoyanov [2], Paraskevas et al. [3], and Paradise-Grenouillet et al. [4]. The life-cycle of metal covers all phases like metal extraction, production, transformation, use, reuse, and recycling $[5,6]$. More industries are currently using a higher quantity and variety of metals in their activities. Metals are fundamental for the development of present day societies, such that world economies have become highly dependent on these resources. There are different metal classifications according to their features. For instance, we can find the main metals which are present in $98 \%$ of the combination masses within industrial metals. They are also available in most services and activities [7]. These main metals are iron, copper, zinc, lead, nickel, and manganese. A common classification of metals distinguishes between ferrous and non-ferrous metals. Critical metals are those with a limited availability due to factors like its geographic localization, difficult extraction, and scarce options of substitution [8]. Some of them are antimony, barium, chromium, manganese, or rare earth elements. Precious metals are those which can be purely found in nature 
without metal combinations like gold, silver, platinum, palladium, and rhodium [9]. In 2009, the global consumption of the main metals was $1725 \mathrm{Mt}$ of iron, 39.3 Mt of aluminum, 15.5 Mt of copper, $11.7 \mathrm{Mt}$ of zinc, and 3.9 Mt of lead [5]. The principle destination of iron ore is steel production, essential in sectors such as aeronautics, the automotive industry, health, construction, etc. [10]. Over the last two decades, the world consumption of iron and bauxite has increased at a higher rate than global GDP [11]. Aluminum can be found in a wide range of products, but is particularly prominent in the food packaging sector [12]. Copper is used in many different applications, such as pipe systems, electrical and electronic appliances, but its primary use over the last two centuries has been in electrical systems [13,14]. Zinc is mainly used for galvanizing steel and other metal alloys. Lead is used as an additive for petrol, but this metal is highly toxic. Nickel is mainly used for producing stainless steel and in the arms industry for armor $[15,16]$. There are also other metals such as platinum, lithium, iridium, palladium, etc., which have gained in prominence in recent years [17]. These metals are used in different electronic devices, catalytic converters, batteries, and a variety of technologies viewed as being respectful to the environment [8]. Over the last few decades, the mining of all of these metals has increased by a rate of over 3\% per year [18]. Furthermore, it is estimated that the global consumption of metals will increase in the future, particularly due to the boost in the development of low-carbon energy infrastructures [11]. Therefore, by 2050, the demand for the seven principle metals could triple relative to $2010[7,19]$.

The continuance of current consumption patterns poses a series of challenges for industry. These include the scarcity of a non-renewable resource, the high costs of mining and processing (economic, energy-related and environmental), and waste management. Many studies have indicated the possibility of a shortage of metals. One of these studies, published in 1972, "Limits of Growth" [20], argued that the supply of a limited resource could not cover the consumption needs of a population with an exponentially increasing demand. Mudd [5] discussed this scenario from the point of view of industry, which defends that technological development, the discovery of new deposits, and the recent evolution of the sector are reasons for an optimistic outlook; as opposed to the hypothesis that population growth and the patterns of global economic development will give rise to a situation of a shortage of metals. More recent studies such as Elshkaki et al. [7], who analyzed different scenarios of the demand for metals, concluded that supply of the principal metals could be assured until 2050, except for copper, zinc, and lead. However, only through reuse and technological improvement, which ensure a more efficient use of minerals, can sustainability be achieved in the sector. The traditional obstacle for the development of the metal recycling industry has been the lack of economic incentive. However, concern regarding a shortage situation, the increase in mining and processing costs (particularly energy costs), and the increase in social pressure to implement cleaner production models constitute incentives for reuse [21]. The potential of metals for reuse and recycling is considerable, as well as transforming them from non-renewable to renewable resources, where these activities imply lower energy consumption and contribute to providing a solution for waste management [8]. Potential recycling rates could reach $90 \%$ for iron and $70 \%$ for aluminum [22,23]. The production of aluminum and nickel is intensive in energy consumption, generating high emissions of greenhouse gases [24]. The production of steel alone represents $25 \%$ of the world's industrial $\mathrm{CO}_{2}$ emissions [25]. For all metals in general, recycling implies a lower consumption of energy and a reduction in environmental pollution to such an extent that the development of recycling, together with the use of renewable energies, would generate a reduction in greenhouse gas emissions of $40 \%$ [24]. The growing interest in reuse and recycling has given rise to a new standard developed by the International Organization for Standardization (ISO) for companies. The ISO/IWA standard guarantees that companies which attain it, implement the correct management of secondary metals [26].

Waste management throughout the whole life cycle of metals constitutes another pressing issue. It poses a risk to the environment (for soil, water, and air) and human health due to the toxicity, inflammability, reactivity, corrosiveness, etc. of this waste [27-29]. There are different types of waste generated in the mining phase of minerals: Solid, tailings, or slurries [30,31]. With respect to processing 
and transformation, the electronics industry alone, one of the principal consumers of metals and the industry with the highest growth rate on a global scale, generated more than 40,000 kt of waste in 2014 from discarded products. In addition, the development of countries such as China has given rise to a large increase in waste generation [32,33]. Moreover, waste management does not only affect the countries in which it is generated. Today, there is a trade of waste which transfers this refuse to third countries. Nations such as China, India, Ghana, or Nigeria receive more than $80 \%$ of the waste generated by the electronics industry in developed countries for their treatment and recycling [32]. The techniques used in these countries with limited legislation and a shortage of qualified workers include practices such as burning and dissolving in acids, which are highly pollutive and have harmful effects on human health. It has been proven that the toxic substances generated in this way are exported again to developed countries through processed food products, creating a cycle of metal pollution on a global level [34].

The greater social awareness of the threats of a shortage of natural resources, the environmental impacts, and the implications for health caused by industrial processes have given rise to an increase in research into sustainable resource management. Therefore, in recent years, there has been an increase in publications on sustainability in different fields, particularly regarding environmental resources [35]. Review papers have been conducted to compile this information for sectors, such as energy [36], forest ecosystems [37], water for irrigation [38], mining waste management [29], case studies in sustainable design approaches in the minerals industry [39], and the crushed stone mining sector [40]. Despite the enormous interest in the sustainability of metals, there is no knowledge of previous studies that have quantitatively and systematically analyzed the dynamics of this line of research. This study seeks to fill this gap in the literature. Therefore, the objective of this study was to analyze the research trends in the sustainable management of metals on a global level during the period 1993-2017. To fulfil this objective, a quantitative review of the sample of articles selected was carried out. The results showed the contributions of this line of research, enabling an identification of the principal driving agents in this field and its future trends.

\section{Materials and Methods}

To achieve the proposed objective, a bibliometric analysis was used. This method can be used to identify, organize, and analyze the principal elements of a research topic [41]. Furthermore, using statistical, mathematical, and mapping tools, it enables the metadata available in the different repositories to be represented, and this determines the trends in the research field [42,43]. The results obtained can be useful for both new and expert researchers as they introduce and assess the scientific activity within the field of study. They may also be of use to analysts and managers in the different decision-making processes $[44,45]$. The use of this methodology offers the possibility of identifying the main driving agents of a research field, such as authors, journals, institutions, or countries [46]; and the collaborative relations that are established between them [47]. The bibliometric method is widely used across a variety of disciplines such as Medicine, Agronomics, Energy, Engineering, Economics, Management, or Biology.

The Scopus database was selected for this study. Scopus is considered to be the largest repository of data referring to citations and summaries of peer-reviewed research literature, including the most relevant publications in each field of study. Scopus guarantees the representativeness of the final sample of documents and the quality of the data [48]. This database provides a wide variety of data on each of the publications, and enables their analysis and comparison. The data may also be downloaded, so that the analysis process can be conducted in different formats [49]. Recent bibliometric studies have used the Scopus database [50-52].

To select the sample of articles to be analyzed in this study, a search was carried out in March 2018 using the following parameters: [TITLE-ABS-KEY (metal); AND TITLE-ABS-KEY (sustainability OR sustainable)]. The search was limited to the period 1993-2017. The final sample did not include work documents, books, and conference documents [53]. The final sample included a total of 6967 documents. The year of publication, subject areas, journals, countries, authors, institutions to which the authors 
are affiliated, and keywords were the analyzed variables. Our analysis included the three types of indicators that are distinguished in bibliometric studies [45]: Productivity, referring to the number of publications; quality, which evaluates the relevance of the publications; and structural indicators, which represent the connections that are established between the different agents. The counting of the documents was used for the productivity analysis of authors, institutions, and countries. The quality indicators selected were the counting of the number of citations, the H index, and the SCImago Journal Rank (SJR) impact factor. The networks of collaboration between the different agents were analyzed using mapping tools and research trends. VOSviewer is a free tool used for processing and grouping words, which enables maps of topographic networks to be viewed by using co-authorship and co-occurrence criteria [54]. Given its suitability for studies based on bibliometric analysis, VOSviewer (version 1.6.5., University of Leiden, Leiden, The Netherlands) was selected to reveal the international collaboration between the different countries and authors, and the research trends using keywords.

The applied analysis of this work could present some methodological limitations. On the one hand, the key word selection can directly affect the results. A search based on other parameters would obviously produce different results. On the other hand, the consulted database could introduce a further limitation. The selected database includes most articles which are also considered by other repositories. However, the results could have been different if we had worked with a different database. In this work, a quantitative study was conducted and can be completed with a qualitative study.

\section{Results and Discussion}

\subsection{The Evolution of Scientific Production}

Table 1 shows the evolution of the group of characteristics of the articles published between 1993 and 2017, which addressed sustainable metals management (SUMM). The analysis focused on the number of articles, the different authors, the number of references, the number of citations, the different journals, and the institutions and countries of affiliation of the authors. The increase in the number of articles published over the last 25 years has been undoubtedly remarkable, rising from three articles in 1993 to 1381 in 2017 . However, more than $63 \%$ of all the publications were concentrated in the last five years of the period studied. This trend reflects the growing interest in this topic on a global level.

The total number of authors who had participated in the publication of the articles analyzed increased from three in 1993 to 4257 in 2017. The average number of authors per article increased from one at the beginning of the period to more than three in 2017. The total number of references increased from 52 in 1993 to 76,968 in 2017. The average number of references per article rose from 17.33 in 1993 to 55.73 in 2017. The number of journals where articles on SUMM had been published increased from three in 1993 to 579 in 2017. In the same way, the number of countries involved in the publication of articles on this topic rose from three in 1993 to 86 in 2017. The number of citations experienced exponential growth, from two in 1994 (year of the first citation obtained from the articles in the sample) to 43.236 in 2017. The average number of citations per article grew from 0.17 in 1994 to 22.99 in 2017. These data support the affirmation that this research topic is undergoing rapid development in terms of its relevance and the volume of publications.

Table 1. Major characteristics of the articles of sustainable metals management (SUMM) from 1993 to 2017.

\begin{tabular}{cccccccccc}
\hline Year & A & AU & AU/A & NR & NR/A & J & C & TC & TC/CA \\
\hline 1993 & 3 & 3 & 1.00 & 52 & 17.33 & 3 & 3 & 0 & 0.00 \\
1994 & 9 & 17 & 1.89 & 198 & 22.00 & 9 & 8 & 2 & 0.17 \\
1995 & 12 & 22 & 1.83 & 178 & 14.83 & 12 & 8 & 8 & 0.42 \\
1996 & 15 & 26 & 1.73 & 262 & 17.47 & 15 & 12 & 24 & 0.87 \\
1997 & 24 & 68 & 2.83 & 514 & 21.42 & 21 & 18 & 32 & 1.05 \\
1998 & 34 & 73 & 2.15 & 1009 & 29.68 & 32 & 15 & 65 & 1.35 \\
\hline
\end{tabular}


Table 1. Cont.

\begin{tabular}{cccccccccc}
\hline Year & A & AU & AU/A & NR & NR/A & J & C & TC & TC/CA \\
\hline 1999 & 36 & 85 & 2.36 & 1322 & 36.72 & 34 & 17 & 90 & 1.66 \\
2000 & 49 & 123 & 2.51 & 1840 & 37.55 & 40 & 18 & 121 & 1.88 \\
2001 & 58 & 146 & 2.52 & 1810 & 31.21 & 51 & 25 & 179 & 2.17 \\
2002 & 58 & 143 & 2.47 & 1335 & 23.02 & 53 & 23 & 294 & 2.73 \\
2003 & 91 & 244 & 2.68 & 2037 & 22.38 & 75 & 32 & 449 & 3.25 \\
2004 & 103 & 270 & 2.62 & 2341 & 22.73 & 88 & 36 & 540 & 3.67 \\
2005 & 136 & 357 & 2.63 & 4332 & 31.85 & 116 & 37 & 846 & 4.22 \\
2006 & 162 & 414 & 2.56 & 4590 & 28.33 & 128 & 38 & 1107 & 4.76 \\
2007 & 178 & 545 & 3.06 & 5150 & 28.93 & 133 & 40 & 1390 & 5.32 \\
2008 & 201 & 670 & 3.33 & 7427 & 36.95 & 153 & 53 & 1886 & 6.02 \\
2009 & 290 & 930 & 3.21 & 11,460 & 39.52 & 216 & 55 & 2856 & 6.78 \\
2010 & 312 & 1047 & 3.36 & 13,411 & 42.98 & 236 & 51 & 4279 & 8.00 \\
2011 & 346 & 1204 & 3.48 & 17,282 & 49.95 & 232 & 56 & 6360 & 9.70 \\
2012 & 426 & 1613 & 3.79 & 22,045 & 51.75 & 270 & 58 & 9194 & 11.69 \\
2013 & 527 & 2038 & 3.87 & 25,756 & 48.87 & 327 & 72 & 12,971 & 13.91 \\
2014 & 630 & 2348 & 3.73 & 33,286 & 52.83 & 364 & 68 & 17,869 & 16.37 \\
2015 & 837 & 3249 & 3.88 & 49,094 & 58.65 & 393 & 75 & 23,878 & 18.61 \\
2016 & 1049 & 4060 & 3.87 & 59,019 & 56.26 & 465 & 81 & 32,529 & 20.94 \\
2017 & 1381 & 4257 & 3.08 & 76,968 & 55.73 & 579 & 86 & 43,236 & 22.99 \\
\hline
\end{tabular}

A: the annual number of articles; AU: the annual number of authors; AU/A: number of authors by article; NR: the number of references in total articles; NR/A: number of references by article; J: the annual number of journals; C: the annual number of countries; TC: the annual number of citations in total articles; TC/CA: annual number of citations by article (annual total citation per cumulative number of publications).

\subsection{Distribution of the Publications by Subject Area and Journal}

Figure 1 shows the evolution of the different subject areas according to the Scopus classification, which that have addressed SUMM during the period analyzed. Although an article may be indexed in more than one category, this does not represent any bias for our results, as the primary objective was to analyze the interconnection between the different categories [55]. The Environmental Science category included most articles for practically over the entirety of the period studied. This category was the first to address this subject with three articles in 1993 and had more than 2600 in 2017, representing $37.69 \%$ of the total articles. This category was followed by Chemistry with $29.25 \%$, Materials Science with $22.84 \%$, Chemical Engineering with 21.23\%, Engineering with $20.67 \%$, and Energy with $16.69 \%$. The rest of the categories accounted for less than $10 \%$ of the total articles. Environmental Science, Engineering, and Chemistry were also among the principle categories of the articles on sustainable management of waste in mining [29]. In recent years, a change in trend has occurred, with technical studies (Engineering and Chemistry) acquiring more relevance and displacing Environmental Science.

Sustainability spans across three fields, namely, environmental, economic, and social dimensions. This characteristic implies the need to address the study of sustainability from different disciplines [56], given that the objective of sustainable management should seek to achieve equitable economic growth, social well-being, and prosperous ecosystems [57]. However, a scarcity of articles on SUMM indexed in the Social Sciences and Economics, Econometrics and Finance categories was observed. Specifically, only $4.07 \%$ and $1.82 \%$ of articles were indexed in this category, respectively. Therefore, a lack in the number of studies analyzing SUMM from a social and economic perspective was identified, indicating that the literature on this subject provided only a partial view of sustainability. These results coincided with the study by Aznar-Sánchez et al. [29]. Similarly, Schoolman et al. [58], in their study on the interdisciplinary nature of the studies on sustainability, concluded that there were fewer studies from an economic perspective. The results of Barbosa et al. [40] also indicated the low relevance of the Economic Sciences. Finally, it is noteworthy that only $1.15 \%$ of the articles were categorized as being multidisciplinary, which highlights the need to promote this type of approach. 


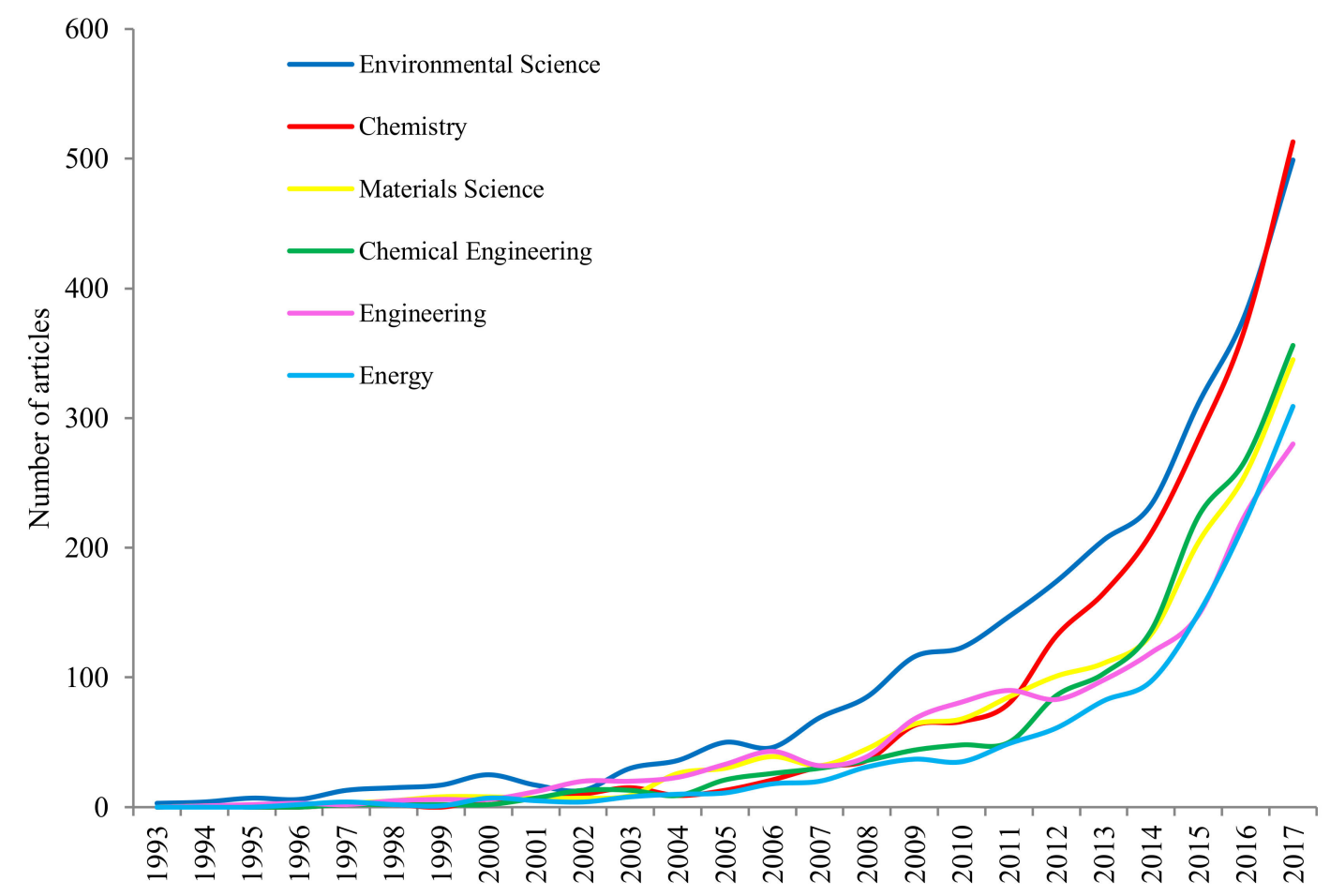

Figure 1. Comparisons of the growth trends of subject areas in SUMM from 1993 to 2017.

Table 2 shows the principle characteristics of the articles on SUMM, published in the most productive journals between 1993 and 2017. It is noteworthy that all of these journals were in the top quantile of the SJR ranking, except for one, and that they all maintained this line of publication given that they had published articles on this subject in 2017. Together, these journals accounted for $15.39 \%$ of the total number of articles in the sample, which indicates a high degree of dispersion in terms of the number of journals that publish content on this subject. The journal that had published the most articles on SUMM was the Journal of Cleaner Production, with a total of 152 articles, representing $2.18 \%$ of the total sample. Its first publication on SUMM dated back to 1996. This journal has an extensive and constant trajectory in this subject area. It had an average of 15.5 citations per article and an $\mathrm{H}$ index of 30. The journal ACS Sustainable Chemistry and Engineering was in second place with 117 articles. Its first publication on SUMM dated back to 2013; however, in only five years, it has placed itself among the top positions. This journal has an average of 7.4 citations per article and an $\mathrm{H}$ index of 20. In third place was Chemsuschem with 112 articles. This journal had an average of 51.1 citations per article and an $\mathrm{H}$ index of 35. The journal with the oldest article, published in 1993, was Science of The Total Environment. The journal with the highest average number of citations per article was Angewandte Chemie International Edition with 116.4. It also had the highest $\mathrm{H}$ index (42).

Some of the most prolific journals in terms of SUMM were also noteworthy with respect to their publication of articles on other subjects related to sustainability, metals, and mining. The Journal of Cleaner Production (position 5), Journal of Environmental Management (position 10), Resources, Conservation and Recycling (position 33), and Science of the Total Environment (position 69) are among the 100 most productive journals in sustainability [47]. Science of The Total Environment is also the second most productive journal in terms of the sustainable management of mining waste [29]. The journals Environmental Science and Pollution Research, Journal of Environmental Management, and Science of The Total Environment also stand out for their publication of articles on soil remediation [59]. 
Table 2. The most active journals in terms of the number of articles on SUMM from 1993 to 2017.

\begin{tabular}{|c|c|c|c|c|c|c|c|c|}
\hline Journal & A & SJR & H Index & $\mathrm{C}$ & TC & TC/A & 1st A & Last A \\
\hline Journal of Cleaner Production & 152 & $1.615(\mathrm{Q} 1)$ & 30 & Netherlands & 2353 & 15.5 & 1996 & 2017 \\
\hline $\begin{array}{l}\text { ACS Sustainable Chemistry } \\
\text { and Engineering }\end{array}$ & 117 & $1.523(\mathrm{Q} 1)$ & 20 & USA & 861 & 7.4 & 2013 & 2017 \\
\hline Chemsuschem & 112 & $2.385(\mathrm{Q} 1)$ & 35 & Germany & 5722 & 51.1 & 2008 & 2017 \\
\hline Green Chemistry & 94 & $2.564(\mathrm{Q} 1)$ & 35 & UK & 3104 & 33.0 & 2004 & 2017 \\
\hline Journal of Materials Chemistry A & 93 & 3.037 (Q1) & 25 & UK & 1383 & 14.9 & 2013 & 2017 \\
\hline $\begin{array}{l}\text { Angewandte Chemie } \\
\text { International Edition }\end{array}$ & 85 & $5.800(\mathrm{Q} 1)$ & 42 & UK & 9890 & 116.4 & 2001 & 2017 \\
\hline Rsc Advances & 83 & $0.875(\mathrm{Q} 1)$ & 17 & UK & 1042 & 12.6 & 2012 & 2017 \\
\hline Waste Management & 75 & $1.354(\mathrm{Q} 1)$ & 22 & UK & 1635 & 21.8 & 2002 & 2017 \\
\hline $\begin{array}{l}\text { Environmental Science and } \\
\text { Pollution Research }\end{array}$ & 69 & $0.813(\mathrm{Q} 2)$ & 18 & Germany & 989 & 14.3 & 2003 & 2017 \\
\hline $\begin{array}{c}\text { Journal of Environmental } \\
\text { Management }\end{array}$ & 64 & 1.141 (Q1) & 19 & USA & 1263 & 19.7 & 2002 & 2017 \\
\hline $\begin{array}{l}\text { Resources, Conservation } \\
\text { and Recycling }\end{array}$ & 64 & $1.160(\mathrm{Q} 1)$ & 26 & Netherlands & 1773 & 27.7 & 1996 & 2017 \\
\hline Science of The Total Environment & 64 & $1.621(\mathrm{Q} 1)$ & 20 & Netherlands & 1069 & 16.7 & 1993 & 2017 \\
\hline
\end{tabular}

A: number of total articles; SJR: Scimago Journal Rank (quartile); C: country; TC: number of citations for all articles; TC/A: number of citations by article; 1st A: first article of SUMM research by journal; Last A: last article of SUMM research by journal.

\subsection{Distribution of Production by Country, Institution and Author}

Table 3 shows the 10 countries that have published the most articles on SUMM in the period from 1993 to 2017. In first place was China with 1347 articles, followed by the United States with 1176, India with 595, Germany with 506, and the United Kingdom with 495. Together, the 10 countries with the most prolific publication accounted for $81.41 \%$ of the total number of articles in the sample. The two leading countries alone represented $36 \%$ of the total. This indicates that, although a large number of countries have undertaken studies on SUMM, there is a central core which represents the main drivers of the research on this subject. The table also shows the evolution of the number of publications per country in five-year periods. Although China began its research into this topic later than other countries, it has been gaining in position among the most active nations and now leads the ranking. In the period 2013-2017, China accounted for more than $25 \%$ of the articles on SUMM published worldwide. The countries which appear in the table were also the most productive in terms of research in the sustainable management of mining waste, except for Japan, Italy, and France. The table also shows that the United States and China had a similar evolution in the number of articles published [29]. China is the principal producer and consumer of metals in the world and over the last few decades, it has experienced spectacular economic growth [60]. These factors have driven research in the mining and metallurgic sectors, and their sustainable management.

To attempt to isolate the effect of size of the country, the number of articles on SUMM per capita was analyzed. The results showed that the country with the greatest number of articles was Australia with 1.32 articles per million inhabitants. This was followed by the United Kingdom with 0.75 , Germany with 0.61 , Spain with 0.59 , and Italy with 0.56 . The table also offers data relating to the impact of the articles based on the number of citations. The United States had the highest average number of citations per article with 36.5, followed by Australia with 36.1, Germany with 35.4, the United Kingdom with 33.8, and Japan with 26.1. Figure 2 shows the relationship between the $H$ index and the total number of articles. A model was used to simulate the increase in the $\mathrm{H}$ index, with the increase in the total number of articles per country over the 25-year period analyzed. 
Table 3. The top 10 most productive countries in SUMM research from 1993 to 2017.

\begin{tabular}{|c|c|c|c|c|c|c|c|c|c|}
\hline \multirow{2}{*}{ Country } & \multirow{2}{*}{ A } & \multirow{2}{*}{ APC } & \multirow{2}{*}{ TC } & \multirow{2}{*}{ TC/A } & \multicolumn{5}{|c|}{$\mathrm{R}(\mathrm{A})$} \\
\hline & & & & & 1993-1997 & 1998-2002 & $2003-2007$ & $2008-2012$ & 2013-2017 \\
\hline China & 1347 & 0.098 & 28,002 & 20.8 & 0 & $10(8)$ & $6(33)$ & $2(183)$ & $1(1123)$ \\
\hline United States & 1176 & 0.364 & 42,911 & 36.5 & $1(11)$ & $1(33)$ & $1(104)$ & $1(267)$ & $2(761)$ \\
\hline India & 595 & 0.045 & 9681 & 16.3 & $4(4)$ & $7(10)$ & $4(41)$ & $5(116)$ & $3(424)$ \\
\hline Germany & 506 & 0.612 & 17,913 & 35.4 & $7(3)$ & $3(26)$ & $3(52)$ & $3(153)$ & $4(272)$ \\
\hline UK & 495 & 0.754 & 16,720 & 33.8 & $10(3)$ & $2(30)$ & $2(72)$ & $4(133)$ & $5(257)$ \\
\hline Italy & 340 & 0.561 & 7407 & 21.8 & 0 & $8(10)$ & $11(23)$ & $8(75)$ & $6(232)$ \\
\hline Japan & 328 & 0.258 & 8574 & 26.1 & $2(5)$ & $4(16)$ & $5(36)$ & $6(95)$ & $11(176)$ \\
\hline Australia & 320 & 1.326 & 11,529 & 36.1 & $3(4)$ & $11(7)$ & $7(32)$ & $7(80)$ & $8(197)$ \\
\hline France & 292 & 0.436 & 6548 & 22.4 & $6(3)$ & $13(6)$ & $12(20)$ & $10(57)$ & $7(206)$ \\
\hline Spain & 273 & 0.588 & 6015 & 22.0 & $13(2)$ & $36(1)$ & $15(10)$ & $9(68)$ & $9(192)$ \\
\hline
\end{tabular}

A: number of total articles; APC: number of articles per 1 million inhabitants; TC: number of citations for all articles; TC/A: number of citations by article; R: ranking position.

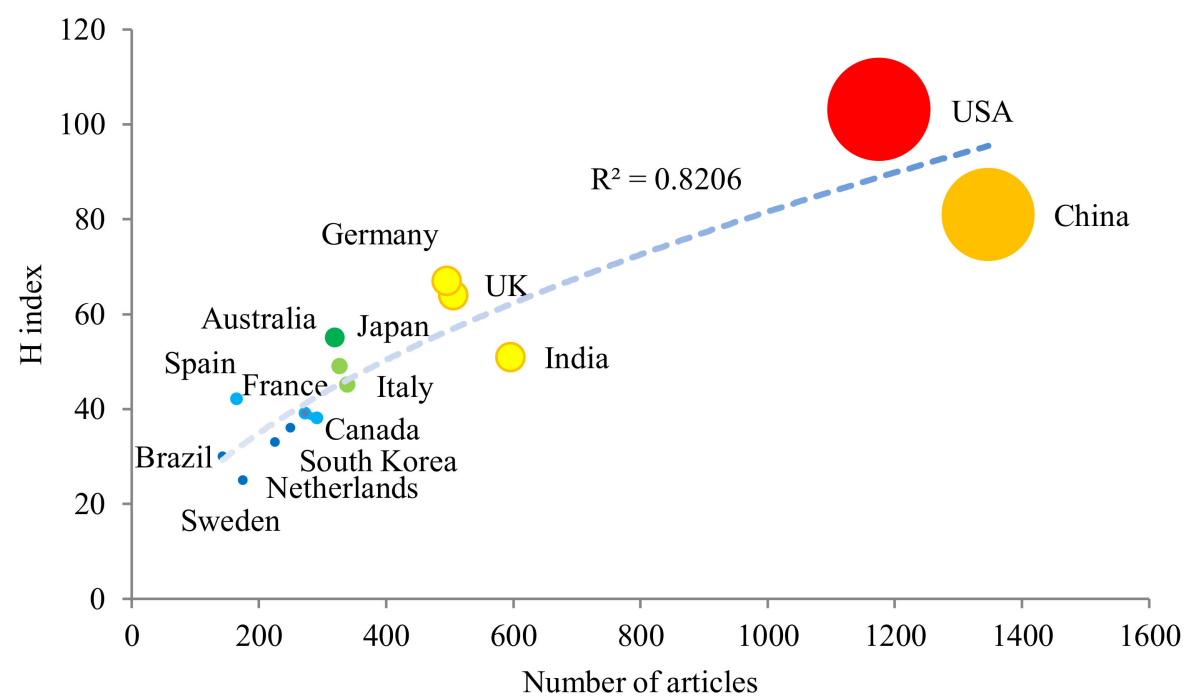

Figure 2. The H index and the total number of articles by country for SUMM research from 1993 to 2017.

Table 4 shows the variables related to the international collaboration between countries. France and Australia were the only two countries with more than half of their articles on SUMM conducted through international collaboration with $54.79 \%$ and $51.25 \%$, respectively. They were followed by Spain with $44.69 \%$, the United Kingdom with $41.82 \%$, and Germany with $41.51 \%$. The United States had the largest network of collaborators with 75 partners, followed by the United Kingdom with 61, Germany with 60, and France with 56. The cases of the United States and Germany were particularly noteworthy, as they form part of the group of principal partners of the other nine countries that make up the top ten. In the majority of cases, the articles written through international collaboration received a higher number of citations than those carried out without international collaboration.

Table 4. The international collaboration between countries on SUMM research from 1993 to 2017.

\begin{tabular}{cccccc}
\hline \multirow{2}{*}{ Country } & \multirow{2}{*}{ IC (\%) } & \multirow{2}{*}{ NC } & Main Collaborators & \multicolumn{2}{c}{ TC/A } \\
\cline { 3 - 5 } & & & & IC & NIC \\
\hline China & 32.00 & 47 & USA, Australia, Japan, Germany, UK & 24.1 & 19.2 \\
USA & 40.82 & 75 & China, UK, Germany, South Korea, Canada & 33.8 & 38.3 \\
India & 24.20 & 51 & USA, South Korea, China, Japan, Germany & 21.4 & 14.6 \\
Germany & 41.51 & 60 & China, USA, UK, Switzerland, Italy & 40.0 & 32.1 \\
\hline
\end{tabular}


Table 4. Cont.

\begin{tabular}{cccccc}
\hline \multirow{2}{*}{ Country } & \multirow{2}{*}{ IC (\%) } & \multirow{2}{*}{ NC } & Main Collaborators & \multicolumn{2}{c}{ TC/A } \\
\cline { 4 - 6 } & & & IC & NIC \\
\hline UK & 41.82 & 61 & USA, China, Germany, Australia, Italy & 40.3 & 29.1 \\
Italy & 34.41 & 52 & Germany, UK, USA, France, Spain & 24.3 & 20.4 \\
Japan & 39.02 & 46 & China, USA, Germany, Australia, India & 31.5 & 22.7 \\
Australia & 51.25 & 48 & China, USA, UK, Japan, Germany & 35.3 & 36.7 \\
France & 54.79 & 56 & USA, Germany, Spain, Belgium, Italy & 18.9 & 26.7 \\
Spain & 44.69 & 48 & France, UK, Italy, Germany, USA & 18.0 & 25.3 \\
\hline
\end{tabular}

IC: international collaborations; NC: total number of international collaborators; TC/A: total citations per article; NIC: no international collaborations.

Figure 3 shows a map of the network based on co-authorship, which represents the international cooperation between the principal countries participating in studies on SUMM. In the map, the color shows the cluster to which the countries belong in accordance with the intensity of their relationships, and the size of the circle varies depending on the number of articles. Four clusters can be observed in the figure. The first (blue) was led by the United States in terms of the number of articles. This cluster also includes countries, such as the United Kingdom, Canada, Mexico, Ireland, Greece, and Turkey. The second group (yellow) was led by China and includes Japan, Australia, New Zealand, and Thailand, among others. The third cluster (green) included India, South Korea, Iran, Russia, and South Africa, among others. The fourth cluster (red) was led by Germany. Certain European countries were also included in this group such as Italy, France, and Spain, together with Brazil, Chile, and Argentina.

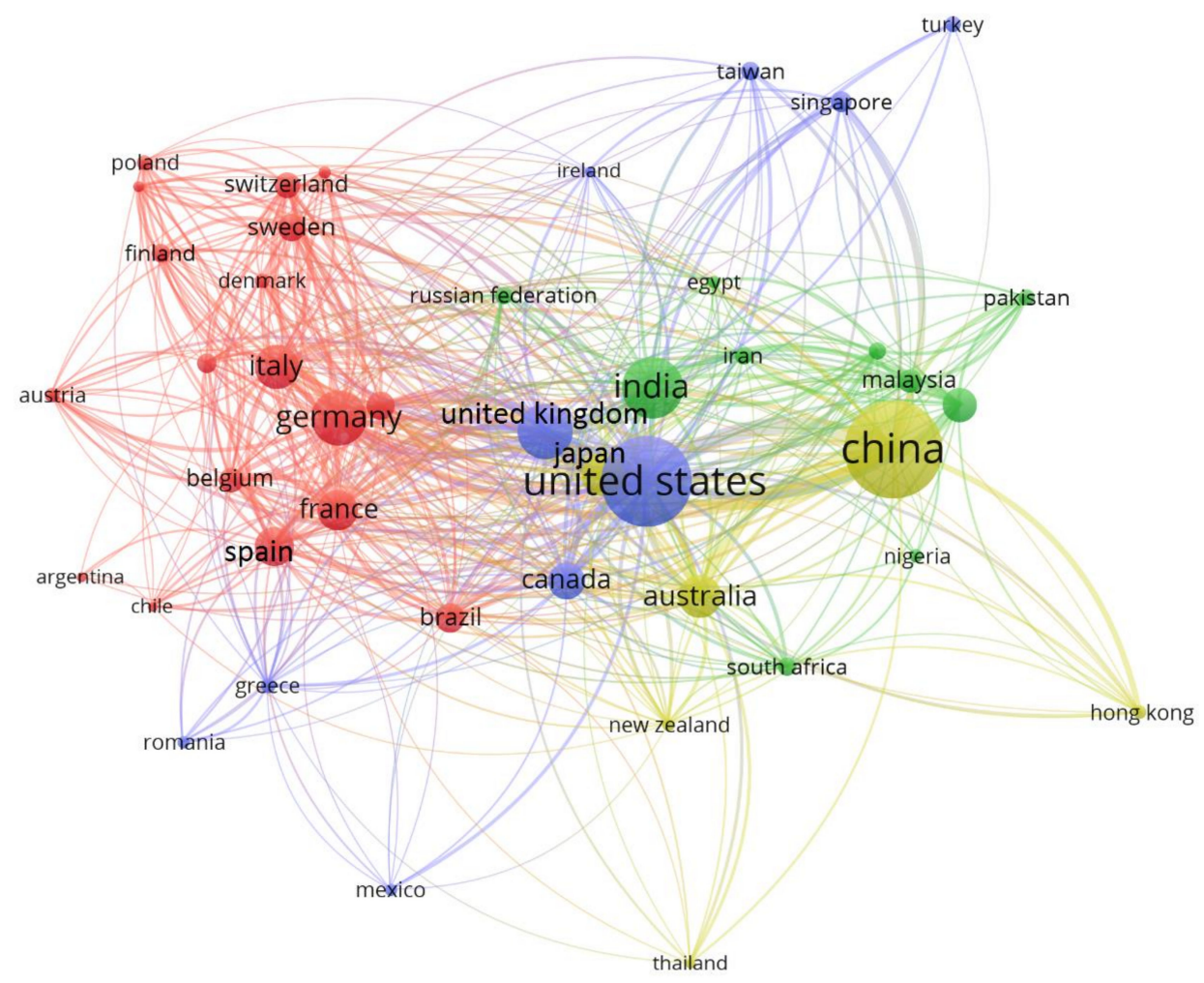

Figure 3. Network of co-authorship-based cooperation between countries from 1993 to 2017.

Table 5 shows the principle characteristics of the articles of the ten most productive institutions in terms of SUMM. The Chinese Academy of Sciences was the institution with the highest number of articles in this field with 260 articles. This institution also had the highest number of citations with 7375, the highest $\mathrm{H}$ index (45), and an average number of citations per article of 28.46 . This was followed by the 
Ministry of Education of China with 133 articles and the Centre National de la Recherche Scientifique with 83. It is noteworthy that although the United States was the second highest country in terms of the number of articles published on SUMM, no institutions from this country were among the 10 most prolific in this respect. The institutions with the highest number of citations per article were the National University of Singapore with 41.4 and the ETH of Zurich with 35.4. Two institutions had more than $50 \%$ of their articles written through international collaboration, namely, the ETH Zurich and the National University of Singapore with 58.82\% and 52.38\%, respectively. The Chinese Academy of Science, Tsinghua University, the ETH of Zurich, and the University of Tokyo had the highest number of citations through international collaboration. The Chinese Academy of Science and the Consejo Superior de Investigaciones Científicas were also among the most productive institutions in terms of the sustainable management of mining waste [30]. China, particularly the Chinese Academy of Science, is particularly noteworthy for the study of coatings of metallic glasses obtained through thermal spraying processes [61]. The table includes the three main journals publishing articles by the most prolific institutions on SUMM. A great diversity can be observed between institutions and the journals they choose to publish in. In can, be generally stated the Asian institutions prefer to publish in ACS Sustainable Chemistry and Engineering, Chemsuschem, Journal of Materials Chemistry A, and Angewandte Chemie International Edition. In fact, the most prolific institution, the Chinese Academy of Science, is the institution with most publications in these journals. Some journals with a high number of articles (Table 2) are not chosen by these institutions, as is the case of the Journal of Cleaner Production. This journal publishes articles from many institutions, but with a lower number of publications.

Table 5. The 10 most productive institutions in SUMM research from 1993 to 2017.

\begin{tabular}{|c|c|c|c|c|c|c|c|c|c|}
\hline \multirow{2}{*}{ Institution } & \multirow{2}{*}{$\mathrm{C}$} & \multirow{2}{*}{$\mathbf{J}$} & \multirow{2}{*}{ A } & \multirow{2}{*}{ TC } & \multirow{2}{*}{ TC/A } & \multirow{2}{*}{ H Index } & \multirow{2}{*}{ IC (\%) } & \multicolumn{2}{|c|}{ TC/A } \\
\hline & & & & & & & & IC & NIC \\
\hline $\begin{array}{l}\text { Chinese Academy } \\
\text { of Sciences }\end{array}$ & China & $\begin{array}{l}\text { J. Materials Chemistry A, } \\
\text { Chemsuschem, Angewandte } \\
\text { Chemie International Edition }\end{array}$ & 260 & 7375 & 28.4 & 45 & 28.46 & 40.2 & 23.7 \\
\hline $\begin{array}{c}\text { Ministry of } \\
\text { Education China }\end{array}$ & China & $\begin{array}{c}\text { ACS Sustainable Chemistry } \\
\text { And Engineering, J. } \\
\text { Hazardous Materials, } \\
\text { Chemsuschem }\end{array}$ & 133 & 3096 & 23.3 & 32 & 30.08 & 12.7 & 27.8 \\
\hline $\begin{array}{l}\text { Centre National de la } \\
\text { Recherche Scientifique }\end{array}$ & France & $\begin{array}{c}\text { Angewandte Chemie } \\
\text { International Edition, } \\
\text { Chemistry A European J., } \\
\text { Advanced Synthesis Catalysis }\end{array}$ & 83 & 2128 & 25.6 & 24 & 45.78 & 16.9 & 33.0 \\
\hline Tsinghua University & China & $\begin{array}{l}\text { Environmental Science } \\
\text { Technology, J. Materials } \\
\text { Chemistry A, ACS Sustainable } \\
\text { Chemistry And Engineering }\end{array}$ & 74 & 1586 & 21.4 & 24 & 25.68 & 22.8 & 20.9 \\
\hline ETH Zurich & Switzerland & $\begin{array}{c}\text { Chemsuschem, } \\
\text { Environmental Science } \\
\text { Technology, ACS Catalysis }\end{array}$ & 51 & 1807 & 35.4 & 19 & 58.82 & 41.0 & 27.5 \\
\hline $\begin{array}{l}\text { Consiglio Nazionale } \\
\text { delle Ricerche }\end{array}$ & Italy & $\begin{array}{l}\text { ACS Catalysis, Environmental } \\
\text { Science Pollution Research, } \\
\text { Pure Applied Chemistry } \\
\text { Spectroscopy Spectral }\end{array}$ & 48 & 945 & 19.7 & 18 & 31.25 & 13.3 & 22.6 \\
\hline Zhejiang University & China & $\begin{array}{c}\text { Analysis, International J. } \\
\text { Advanced Manufacturing } \\
\text { Technology, J. Materials } \\
\text { Chemistry A }\end{array}$ & 46 & 1077 & 23.4 & 18 & 26.09 & 18.5 & 25.1 \\
\hline $\begin{array}{l}\text { Consejo Superior de } \\
\text { Investigaciones } \\
\text { Científicas }\end{array}$ & Spain & $\begin{array}{l}\text { Atmospheric Environment, } \\
\text { Chemistry A European } \\
\text { Journal, Green Chemistry }\end{array}$ & 44 & 943 & 21.4 & 16 & 40.91 & 11.0 & 28.7 \\
\hline
\end{tabular}


Table 5. Cont.

\begin{tabular}{|c|c|c|c|c|c|c|c|c|c|}
\hline \multirow{2}{*}{ Institution } & \multirow{2}{*}{ C } & \multirow{2}{*}{$\mathbf{J}$} & \multirow{2}{*}{$\mathbf{A}$} & \multirow{2}{*}{ TC } & \multirow{2}{*}{ TC/A } & \multirow{2}{*}{ H Index } & \multirow{2}{*}{ IC (\%) } & \multicolumn{2}{|c|}{ TC/A } \\
\hline & & & & & & & & IC & NIC \\
\hline University of Tokyo & Japan & $\begin{array}{l}\text { Angewandte Chemie } \\
\text { International Edition, } \\
\text { Biochimica Et Biophysica Acta } \\
\text { Bioenergetics, Computer } \\
\text { Aided Chemical Engineering }\end{array}$ & 44 & 1141 & 25.9 & 19 & 27.27 & 34.7 & 22.7 \\
\hline
\end{tabular}

C: country; J: main 3 journals by institution; A: number of total articles; TC: number of citations in total articles;

TC/A: number of citations by article; IC: international collaborations; NIC: no international collaborations.

Table 6 shows the principle characteristics of the articles from the most productive authors in terms of SUMM. The author who had published the most articles was Thomas E. Graedel from Yale University with a total of 19 . This author had accumulated 1225 citations and an average of 64.5 citations per article, an $\mathrm{H}$ index of 15, and published for the first time in this field in 2006. In second place was Markus Antonietti from the Max Planck Institut in Potsdam with 18 articles. This was the author with the most number of citations at 3217. Furthermore, he also had the highest average number of citations per article at 178.7. His $\mathrm{H}$ index was 15 and his first article within the data sample was published in 2006. In third place was Katsuomi Takehira from Hiroshima University, with 16 articles. This author had a total of 786 citations, an average of 49.1 citations per article, and an $\mathrm{H}$ index of 14 . This author was also the most veteran of the most active researchers in this subject as his first article was published in 1997. The author who had most recently been incorporated into this line of research was Jinhui Li, whose first article within the data sample was published in 2015. In just two years, this author has positioned himself among the most prolific authors with 11 articles.

Table 6. The most productive authors in SUMM research from 1993 to 2017.

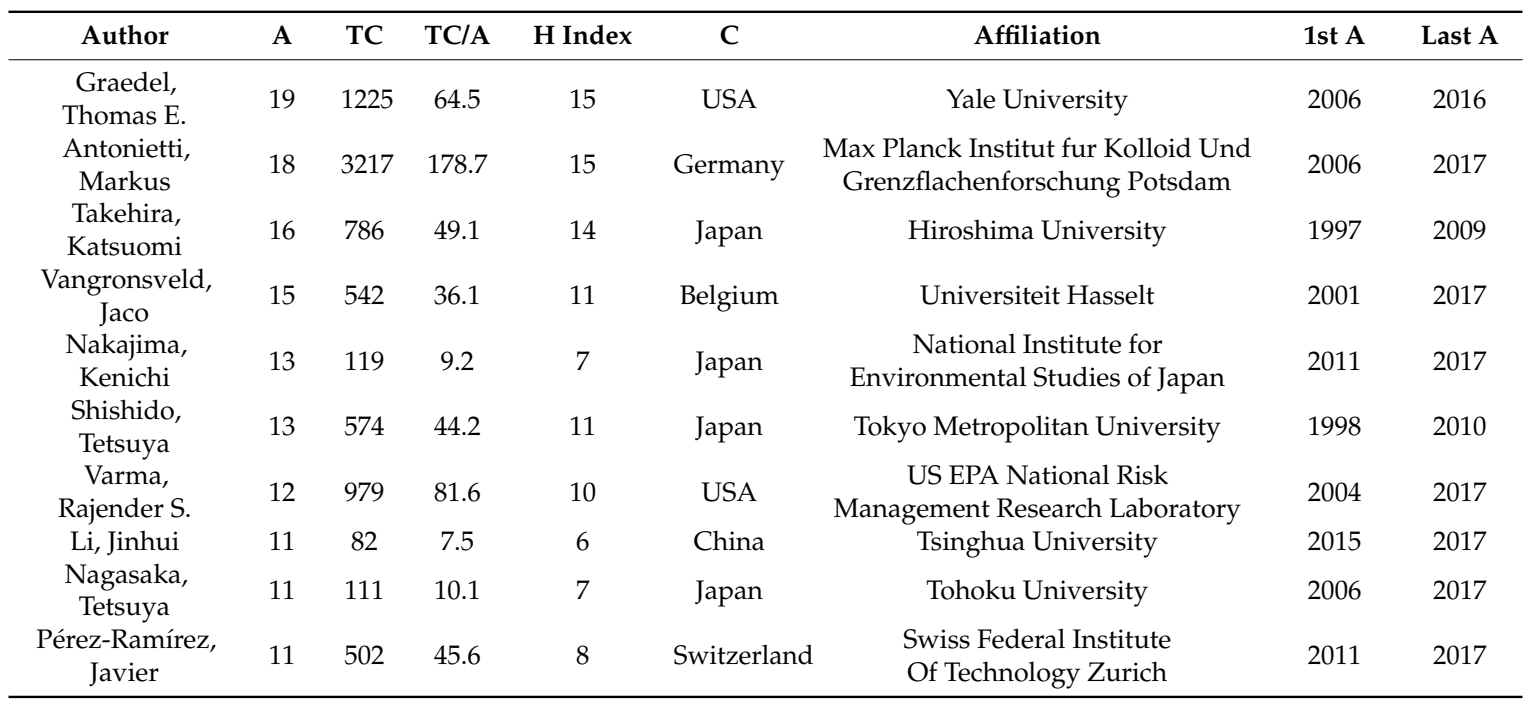

A: number of total articles; TC: number of citations in total articles; TC/A: number of citations by article; C: country; 1st A: first article of SUMM research by author; Last A: last article of SUMM research by author.

Figure 4 shows a network map based on co-authorship, which represents the collaboration network among the principal authors participating in the publication of articles on SUMM in the period 1993-2017. In this map of collaborations, different clusters shown in different colors can be observed, and the size of the circle varied depending on the number of articles. The figure shows a central core that groups together different clusters made up of mainly Asian authors. Within this core, there was a cluster led by Antonietti and included others, such as Fellinger, Giordano, or Fischer, 
together with Chinese authors. Of the peripheral clusters, the one led by Graedel is noteworthy. This group also included Harper and Nassar, among others. Takehira and Shishido were found in the same group, together with Li. Vangronsveld was in the same group as Witters, Meers, and Ruttens. In the group led by Nakajima, we also found Nagasaka, Nakamura, and Matsubae. Varma was in the same group as Dutta and Gawande, among others. Li was in the central core group together with the likes of Zeng, Tan, Lu, and Liu. Finally, Pérez-Ramírez was in the same cluster as authors, such as Mondelli and López.

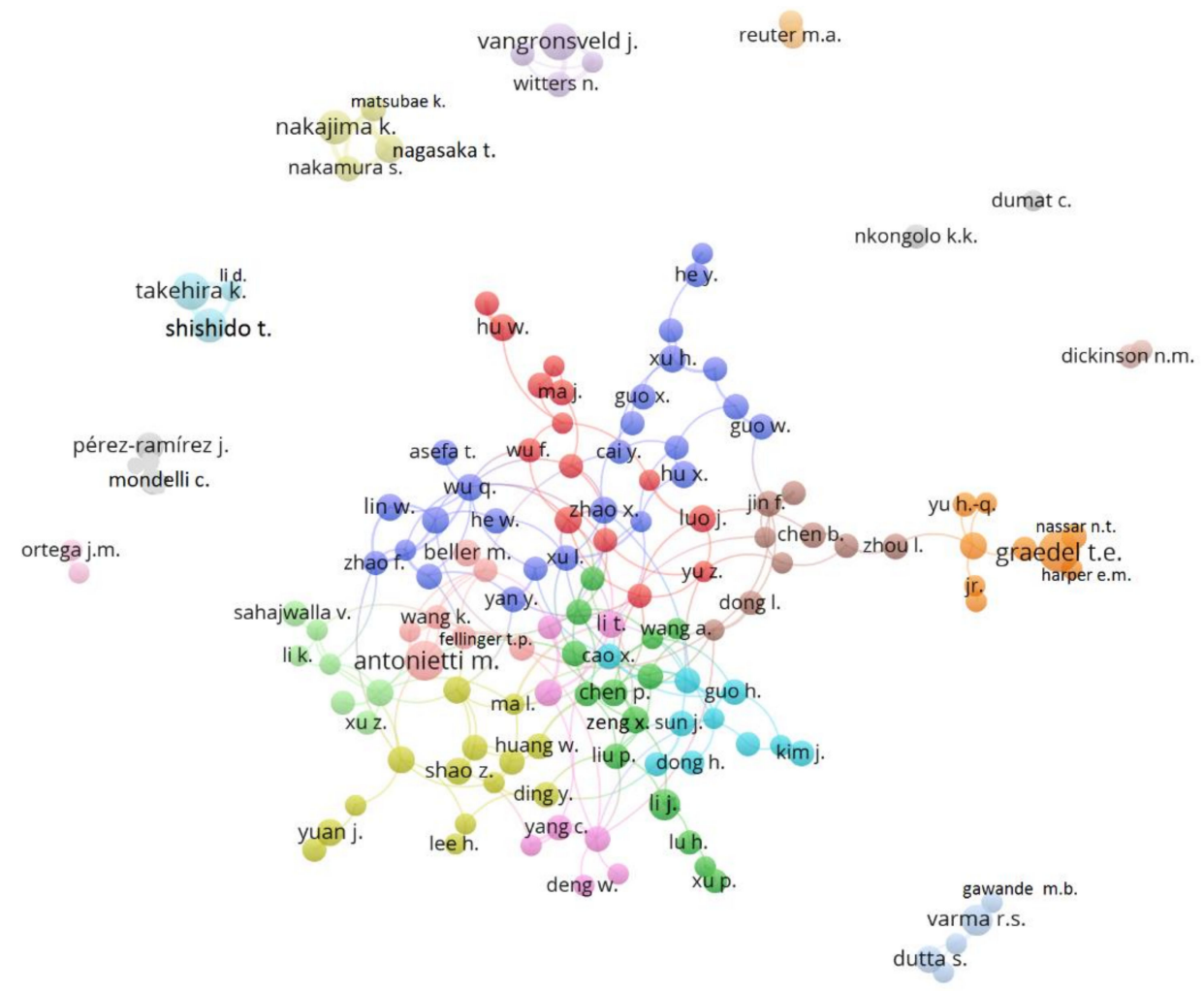

Figure 4. Network of cooperation based on co-authorship between authors from 1993 to 2017.

\subsection{Analysis of Keywords}

To illustrate the evolution of the different trends in the study of SUMM, an analysis of the keywords used in the articles in the sample was carried out. To avoid double counting, words in plural form, words with hyphens, and words written in uppercase letters were eliminated [38]. After regrouping the terms, a total of 38.596 keywords were obtained from the 6967 articles subject to analysis. The analysis did not consider terms used as search parameters of the sample of articles (metal, sustainability, and sustainable), but it did consider possible combinations of these terms. Table 7 shows the 20 most used keywords during the whole period of study, and also in different five-year sub-periods.

For the whole period, the most used term was sustainable-development. Heavy metals, copper, zinc, lead, carbon, nickel, and iron were the most studied minerals and metals. Chemistry was the leading discipline and technical studies were predominant; whilst catalytic processes, nanotechnology, and controlled studies constituted the most used methodological terms. Environmental impact, recycling, waste management, soil pollution, and the non-human factor were the most relevant themes. There were no terms related to social or economic issues. The findings revealed that throughout the whole period, there was a series of terms that remained in the top positions, such as heavy-metals, sustainable-development, recycling, and environmental-impact. It is noteworthy that the only metal that predominated throughout all of the sub-periods was copper, as opposed to others that can be considered as being more pollutive, such as lead, given the high consumption of fuels, or aluminum, 
the production process of which requires a high consumption of energy with the resulting emissions of greenhouse gases.

The period 1993-1997 was remarkable, as it focused on the management of industrial waste and the control of pollution on an ecosystem level, particularly in agriculture. In no other period was a particular interest in this type of ecosystem evident. The period 1998-2002 was characterized by a clear predominance of environmental issues, together with economic and social factors. Environmental and impact assessment, environmental management, and monitoring were priority subject areas. During this period, the economic and social analyses were particularly relevant. This turnaround in the principal topics of the research on sustainable management of metals may be due to the influence of the first ecosystem assessments, which culminated in the Millennium Ecosystem Assessment in 2005 [62]. On a geographic level, the United States stood out as an object of study. Within the different phases of the life cycle of metals, mining activity was prominent.

The period 2003-2007 represented a new change in research trends. The main topics were waste management, environmental sustainability, and industrial economics. In this period, the focus was not only on soil pollution; for the first time, water pollution was also analyzed. With respect to the previous period, the studies concentrated on Europe and Asia. In the period 2008-2012, there was a reduction in the economic-based analyses and an increase in technical studies. For the first time, Chemistry as a discipline, appeared among the principal terms. Catalytic processes and controlled studies displaced industrial economics. In addition to recycling, for the first time, an emphasis was placed on the recovery of metals. The last five-year period (2013-2017) brought about the consolidation of the technical studies in the development of research on SUMM. Nanotechnology emerged among the most used terms. Keywords referring to soil disappeared and were replaced by concepts such as catalysts, catalysis, metal-nanoparticles, nanoparticles, electrodes, metal-ions, catalyst-activity, and procedures.

Figure 5 shows a network map based on the co-occurrence of the principal keywords. The size of the circle varied depending on the number of repetitions and the color used to differentiate the different groups was based on the number of co-occurrences. Three clusters can be observed, which represent the main lines of research in SUMM. Red corresponds to a line of study focused on decontamination. Bioremediation and phytoremediation processes are prominent both in water and soil, mainly affected by heavy metals. Blue represents the line of research on waste, reuse, and recycling. This line is based on circular economy processes and seeks to perpetuate the life of materials to limit the shortage of resources, reduce energy consumption and pollution. The green cluster represents the area of research studying the improvement of technology and processes, which aims to achieve a cleaner production and a better use of mineral grades.

The main differentiating factor among these three lines of research and the explanation of their observed trends is in the analysis focus. Although multidisciplinary characterizes sustainability studies, in each research trend there prevails a different theoretical approach. A research line focuses on environment, another one on economics, and the third one on technics and chemistry. Moreover, these research lines study different phases of the metal lifecycle. Metal pollution is present along its whole life, but most literature within the red cluster concentrates on pollution during extraction. Mining is considered one of the main polluting sources on earth. This cluster has most studies with an environmental perspective. This field shows the highest number of published articles (Figure 1). Activities related to the blue cluster-recycling, reuse, and waste management-refer to the final phases of transformation and metal consumption. In this research line prevail economic studies. Technological developments are shown by the green cluster and is present in the exploration and extraction phases, as well as in recycling and reuse. However, technology gains its highest relevance in the metal transformation phase. Engineering and chemistry dominate in this cluster. 
Table 7. Main 20 keywords from 1993 to 2017 by period.

\begin{tabular}{|c|c|c|c|c|c|c|c|c|c|c|c|}
\hline \multicolumn{2}{|l|}{ 1993-2017 } & \multicolumn{2}{|c|}{ 1993-1997 } & \multicolumn{2}{|l|}{ 1998-2002 } & \multicolumn{2}{|l|}{ 2003-2007 } & \multicolumn{2}{|l|}{ 2008-2012 } & \multicolumn{2}{|l|}{ 2013-2017 } \\
\hline Keyword & $\%$ & Keyword & $\%$ & Keyword & $\%$ & Keyword & $\%$ & Keyword & $\%$ & Keyword & $\%$ \\
\hline $\begin{array}{l}\text { Sustainable- } \\
\text { Development }\end{array}$ & 18.66 & Heavy-Metals & 17.46 & $\begin{array}{l}\text { Sustainable- } \\
\text { Development }\end{array}$ & 34.89 & $\begin{array}{l}\text { Sustainable- } \\
\text { Development }\end{array}$ & 36.87 & $\begin{array}{l}\text { Sustainable- } \\
\text { Development }\end{array}$ & 18.60 & $\begin{array}{l}\text { Sustainable- } \\
\text { Development }\end{array}$ & 15.08 \\
\hline Heavy-Metals & 14.68 & $\begin{array}{l}\text { Sustainable- } \\
\text { Development }\end{array}$ & 17.46 & Heavy-Metal & 19.15 & Heavy-Metal & 19.10 & Heavy-Metals & 15.87 & Heavy-Metals & 14.10 \\
\hline $\begin{array}{l}\text { Catalysts } \\
\text { Recycling }\end{array}$ & $\begin{array}{c}10.77 \\
9.23\end{array}$ & $\begin{array}{l}\text { Copper } \\
\text { Recycling }\end{array}$ & $\begin{array}{l}15.87 \\
12.70\end{array}$ & $\begin{array}{c}\text { Recycling } \\
\text { Environmental-Impact }\end{array}$ & $\begin{array}{l}9.79 \\
8.94\end{array}$ & $\begin{array}{c}\text { Recycling } \\
\text { Environmental-Impact }\end{array}$ & $\begin{array}{l}12.09 \\
10.60\end{array}$ & $\begin{array}{l}\text { Recycling } \\
\text { Catalysis }\end{array}$ & $\begin{array}{l}10.41 \\
8.95\end{array}$ & $\begin{array}{l}\text { Catalysts } \\
\text { Chemistry }\end{array}$ & $\begin{array}{l}13.90 \\
10.38\end{array}$ \\
\hline Catalysis & 8.55 & $\begin{array}{l}\text { Environmental- } \\
\text { Impact }\end{array}$ & 12.70 & $\begin{array}{l}\text { Environmental- } \\
\text { Protection }\end{array}$ & 7.23 & Copper & 9.85 & Zinc & 8.06 & Catalysis & 9.65 \\
\hline Chemistry & 8.40 & Zinc & 12.70 & Waste-Management & 5.96 & Eurasia & 9.25 & Copper & 7.75 & Recycling & 8.30 \\
\hline Copper & 7.45 & Cadmium & 11.11 & $\begin{array}{l}\text { Economic-And- } \\
\text { Social-Effects }\end{array}$ & 5.53 & Waste-Management & 8.06 & Metal-Recovery & 7.62 & Nanoparticles & 7.44 \\
\hline Zinc & 6.24 & Lead & 9.52 & Mining & 5.11 & Lead & 7.46 & Lead & 7.30 & Carbon & 7.32 \\
\hline $\begin{array}{l}\text { Environmental- } \\
\text { Impact }\end{array}$ & 5.97 & Agriculture & 9.52 & Soil & 4.68 & Zinc & 6.72 & Chemistry & 7.11 & Copper & 7.03 \\
\hline Lead & 5.96 & Ecosystem & 7.94 & Soil-Pollution & 4.68 & Mining & 6.57 & Soils & 6.86 & Metal-Nanoparticles & 6.80 \\
\hline Nanoparticles & 5.93 & Soil & 7.94 & Aluminum & 4.26 & Europe & 6.12 & Waste-Management & 6.60 & Nickel & 5.81 \\
\hline Carbon & 5.60 & Aluminum & 7.94 & Copper & 4.26 & Cadmium & 5.82 & Controlled-Study & 6.54 & Carbon-Dioxide & 5.76 \\
\hline Soils & 5.43 & Waste-Disposal & 7.94 & Industrial-Economics & 4.26 & Nickel & 5.67 & Iron & 6.29 & Electrodes & 5.63 \\
\hline Waste-Management & 5.38 & Soil-Pollution & 7.94 & $\begin{array}{l}\text { Environmental- } \\
\text { Management }\end{array}$ & 3.83 & Soil & 5.52 & Catalysts & 6.22 & Zinc & 5.63 \\
\hline $\begin{array}{c}\text { Nickel } \\
\text { Metal-Nanoparticles }\end{array}$ & $\begin{array}{l}5.34 \\
5.15\end{array}$ & $\begin{array}{l}\text { Nonhuman } \\
\text { Human }\end{array}$ & $\begin{array}{l}7.94 \\
6.35\end{array}$ & $\begin{array}{l}\text { Biomass } \\
\text { United-States }\end{array}$ & $\begin{array}{l}3.40 \\
3.40\end{array}$ & $\begin{array}{l}\text { Soil-Pollution } \\
\text { Chromium }\end{array}$ & $\begin{array}{l}5.07 \\
4.93\end{array}$ & $\begin{array}{l}\text { Soil-Pollution } \\
\text { Biomass }\end{array}$ & $\begin{array}{l}5.90 \\
5.78\end{array}$ & $\begin{array}{l}\text { Metal-Ions } \\
\text { Catalyst-Activity }\end{array}$ & $\begin{array}{l}5.56 \\
5.40\end{array}$ \\
\hline Controlled-Study & 5.10 & Industrial-Waste & 6.35 & $\begin{array}{l}\text { Environmental- } \\
\text { Impact-Assessment }\end{array}$ & 3.40 & $\begin{array}{l}\text { Environmental- } \\
\text { Sustainability }\end{array}$ & 4.93 & Cadmium & 5.78 & Lead & 5.33 \\
\hline Nonhuman & 5.10 & Pollution & 6.35 & $\begin{array}{l}\text { Environmental- } \\
\text { Monitoring }\end{array}$ & 3.40 & Water-Quality & 4.93 & $\begin{array}{l}\text { Environmental- } \\
\text { Impact }\end{array}$ & 5.71 & Nonhuman & 5.24 \\
\hline Carbon-Dioxide & 4.92 & Pollution-Control & 6.35 & $\begin{array}{l}\text { Environmental- } \\
\text { Assessment }\end{array}$ & 3.40 & Industrial-Economics & 4.78 & Nonhuman & 5.46 & Procedures & 5.18 \\
\hline Iron & 4.85 & Nickel & 6.35 & Waste-Disposal & 3.40 & Aluminum & 4.63 & Adsorption & 5.02 & Environmental-Impact & 5.11 \\
\hline
\end{tabular}




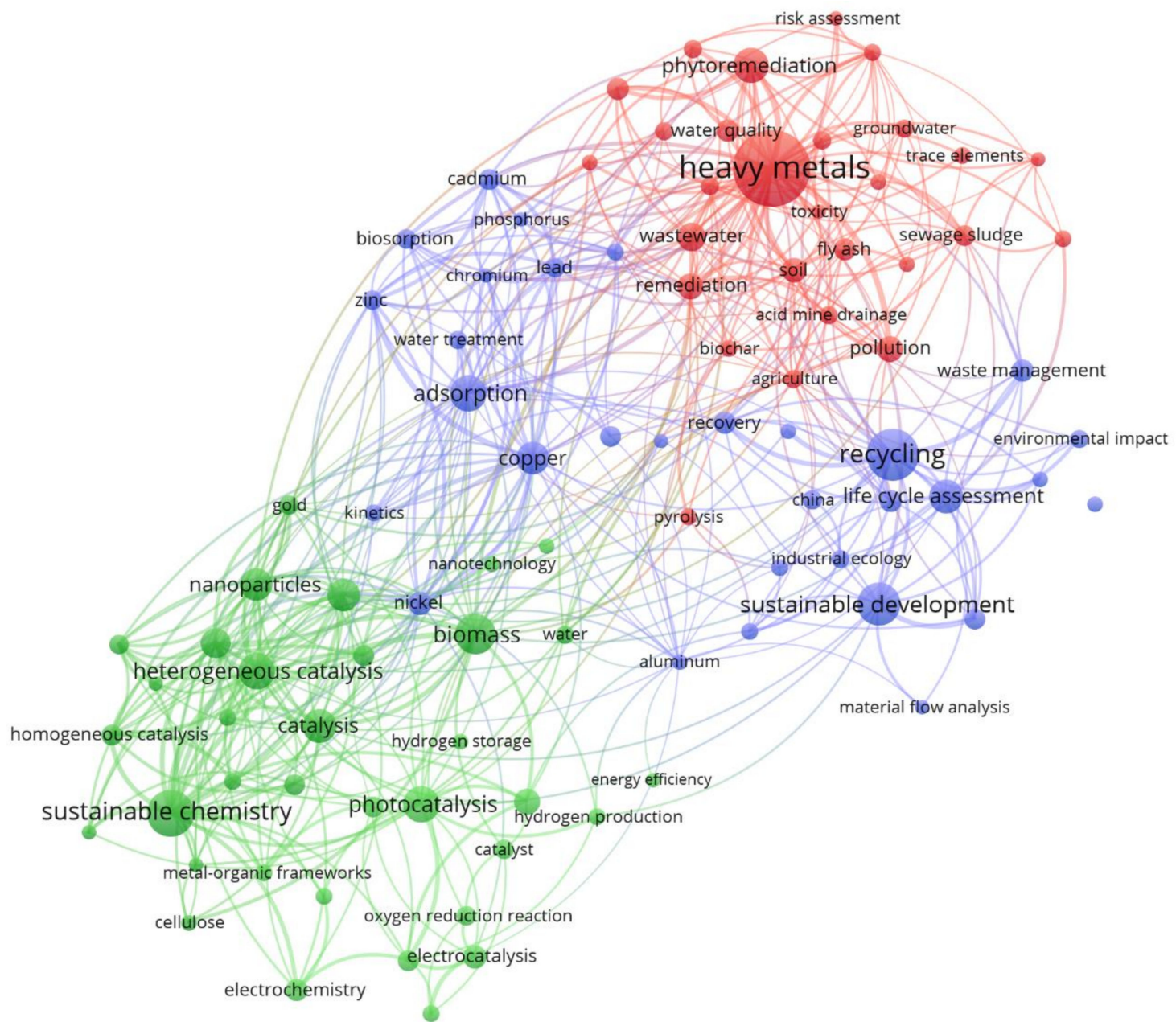

Figure 5. Network of the main keyword co-occurrences in SUMM research from 1993 to 2017.

\section{Conclusions}

The main objective of this study was to analyze the evolution of the research on sustainable management of metals over the last 25 years. To achieve this objective, a bibliometric analysis was conducted on a total sample of 6967 articles. The variables analyzed were author, number of articles published per year, subject area, journal, countries, institutions, and keywords. The results showed a remarkable increase in the number of articles published, particularly during the last five years of the study where more than $63 \%$ of the total were concentrated. The increase in both the number of publications and the number of authors and countries involved in the studies on sustainable management of metals, shows that there is growing interest in this line of research on a global scale. This trend is due to the growing social awareness of the impact of climatic change, and the need to develop sustainable patterns and transfer them to the political and business spheres.

The country at the top of the ranking in terms of greatest scientific production regarding the sustainable management of metals was China. Despite that it started research in this field later than other countries, China has been able to position itself as a leader in the study of this subject, and in recent years has accounted for $25 \%$ of the total articles published worldwide. It was followed by the United States, India, Germany, and the United Kingdom. However, in terms of publications per capita, the ranking was led by Australia, the United Kingdom, and Germany. The most relevant countries based on the number of citations were the United States, Australia, and Germany. The establishment of a large network of collaborations between the different countries for the joint publication of studies in this field was noteworthy. The three authors with the most publications on the sustainable management 
of metals were Graedel, Antonietti, and Takehira. There was a predominance of Japanese authors among the ten authors with the most publications in this field.

The analysis of keywords showed that the three principal lines of research in this subject were metal decontamination of both water and soil; waste management oriented towards the development of circular economy processes based on reuse and recycling; and the development of the innovation of processes that give rise to cleaner, less pollutive, and more efficient production with lower energy consumption, which generates less waste and enables a better use of the mineral. The explanation of these three lines of research lies in their study focus. The first one bases on an environmental focus, the second one on an economical approach, and the third one on engineering and chemistry.

Regarding the three dimensions of sustainability (environment, economics and society), the study also highlighted the lack of attention given by research in the sustainable management of metals to economic and social dimensions. We believe that future lines of research should incorporate these dimensions, together with the environmental aspect to establish truly sustainable development models, which ensure a supply of the resource that is respectful of the environment and contributes to economic development and social well-being. De-pollution works focus on environmental and technical aspects. This line of research includes social perceptions and preferences about the final use of abandoned mining infrastructures and waste produced along the whole metal life. Moreover, possible exploitation alternatives should be studied to produce both economic and social wealth. In works on metal recycling, reuse and recuperation, and technical development should be considered, as well as the stakeholders' consent for its implementation. Governments should provide a proper legal framework to develop mining activities, a global enterprise structure should be provided and public participation should be fostered and educated on. Finally, technical works focus on process efficiency and technological development, but they do not consider general social dimensions. Technological developments should serve society considering population needs and preferences, especially those of neighborhoods where exploitations and industry are located.

In the study of sustainable management of metals, it is necessary to develop comprehensive analysis and assessment frameworks that imply the cooperation of different disciplines within the same analytical structure, and which ensure their joint contribution in the ecological, economic, and social dimensions of sustainability.

Author Contributions: The four authors have equally contributed to this paper. All authors have revised and approved the final manuscript.

Acknowledgments: This work has been partially supported by the Spanish Ministry of Economy and Competitiveness and the European Regional Development Fund by means of the research project ECO2017-82347-P and HAR2014-56428-C3-2, and by the Research Plan of the University of Almería through a Predoctoral Contract to Juan F. Velasco Muñoz.

Conflicts of Interest: The authors declare no conflict of interest.

\section{References}

1. Brundtland, G.; Khalid, M.; Agnelli, S.; Al-Athel, S.; Chidzero, B.; Fadika, L.; Hauff, V.; Lang, I.; Ma, S.; Morino de Botero, M.; et al. Our Common Future ('Brundtland report'); Oxford University Press: Oxford, UK, 1987; p. 383. ISBN 019282080X.

2. Nath, B.; Stoyanov, S. Sustainable management of metals. J. Chem. Technol. Metall. 2014, 49, 170-178.

3. Paraskevas, D.; Kellens, K.; Dewulf, W.; Duflou, J.R. Environmental modelling of aluminum recycling: A Life Cycle Assessment tool for sustainable metal management. J. Cleaner Prod. 2015, 105, 357-370. [CrossRef]

4. Paradis-Grenouillet, S.; Allée, P.; Servera-Vives, G.; Ploquin, A. Sustainable management of metallurgical forest on Mont Lozère (France) during the Early Middle Ages. Environ. Archaeol. 2015, 20, 168-183. [CrossRef]

5. Mudd, G.M. The "Limits to Growth" and "Finite" Mineral Resources: Re-visiting the Assumptions and the Drinking From Half-Capacity Glass. Int. J. Sustain. Dev. 2013, 16, 204-220. [CrossRef] 
6. Gorman, M.R.; Dzombak, D.A. A review of sustainable mining and resource management: Transitioning from the life cycle of the mine to the life cycle of the mineral. Resour. Conserv. Recycl. 2018, 137, 281-291. [CrossRef]

7. Elshkaki, A.; Graedel, T.E.; Ciacci, L.; Reck, B.K. Resource Demand Scenarios for the Major Metals. Environ. Sci. Technol. 2018, 52, 2491-2497. [CrossRef] [PubMed]

8. Ilyas, S.; Kim, M.S.; Lee, J.C.; Jabeen, A.; Bhatti, H.N. Bio-Reclamation of Strategic and Energy Critical Metals from Secondary Resources. Metals 2017, 7, 207. [CrossRef]

9. Carvalho, F.P. Mining industry and sustainable development: Time for change. Food Energy Secur. 2017, 6, 61-77. [CrossRef]

10. Bucur, A.; Dobrotă, G.; Oprean-Stan, C.; Tănăsescu, C. Economic and Qualitative Determinants of the World Steel Production. Metals 2017, 7, 163. [CrossRef]

11. Wiedmann, T.O.; Schandl, H.; Moran, D. The footprint of using metals: New metrics of consumption and productivity. Environ. Econ. Policy Stud. 2015, 17, 369-388. [CrossRef]

12. Jellesen, M.S.; Rasmussen, A.A.; Hilbert, L.R. A review of metal release in the food industry. Mater. Corros. 2006, 58, 387-393. [CrossRef]

13. Mudd, G.M. The Environmental sustainability of mining in Australia: Key mega-trends and looming constraints. Resour. Policy 2010, 35, 98-115. [CrossRef]

14. Irfan, O.M.; Mukras, S.M.S.; Al-Mufadi, F.A.; Djavanroodi, F. Surface Modelling of Nanostructured Copper Subjected to Erosion-Corrosion. Metals 2017, 7, 155. [CrossRef]

15. Mudd, G.M. Global trends and environmental issues in nickel mining: Sulfides versus laterites. Ore Geol. Rev. 2010, 38, 9-26. [CrossRef]

16. Schaffartzik, A.; Mayer, A.; Eisenmenger, N.; Krausmann, F. Global patterns of metal extractivisim, 1950-2010: Providing the bones for the industrial society's skeleton. Ecol. Econ. 2016, 122, 101-110. [CrossRef]

17. Chen, W.S.; Ho, H.J. Recovery of Valuable Metals from Lithium-Ion Batteries NMC Cathode Waste Materials by Hydrometallurgical Methods. Metals 2018, 8, 321. [CrossRef]

18. Gordon, R.B.; Bertram, M.; Graedel, T.E. Metal stocks and sustainability. Proc. Natl. Acad. Sci. USA 2006, 103, 1209-1214. [CrossRef] [PubMed]

19. United States Geological Survey. Available online: http://minerals.usgs.gov/minerals/. (accessed on 7 March 2018).

20. Meadows, D.H.; Meadows, D.L.; Randers, J.; Behrens, W.W. The Limits to Growth: A Report for the Club of Rome's Project on the Predicament of Mankind; Potomac-Earth Island: London, UK, 1972.

21. Ayres, R.U. Metals recycling: Economic and environmental implications. Resour. Conserv. Recycl. 1997, 21, 145-173. [CrossRef]

22. Graedel, T.E.; Allwood, J.; Birat, J.P.; Buchert, M.; Hagelüken, C.; Reck, B.K.; Sibley, S.F.; Sonnemann, G. What Do We Know About Metal Recycling Rates? J. Ind. Ecol. 2011, 15, 355-366. [CrossRef]

23. Capuzzi, S.; Timelli, G. Preparation and Melting of Scrap in Aluminum Recycling: A Review. Metals 2018, 8, 249. [CrossRef]

24. Van der Voet, E.; Van Oers, L.; Verboon, M.; Kuipers, K. Environmental Implications of Future Demand Scenarios for Metals: Methodology and Application to the Case of Seven Major Metals. J. Ind. Ecol. 2018. [CrossRef]

25. Cullen, J.M.; Allwood, J.M.; Bambach, M.D. Mapping the global flow of steel: From steelmaking to end-use goods. Environ. Sci. Technol. 2012, 46, 13048-13055. [CrossRef] [PubMed]

26. International Standardization Organization (ISO). Guidance Principles for the Sustainable Management of Secondary Metals. International Standard ISO/IWA 19:2017. 2017. Available online: https://www.iso.org/ standard/69354.html (accessed on 15 March 2018).

27. Fan, S.; Wang, X. Analysis and assessment of heavy metals pollution in soils around a $\mathrm{Pb}$ and $\mathrm{Zn}$ smelter in Baoji City. Northwest China. Hum. Ecol. Risk Assess. 2017, 23, 1099-1120. [CrossRef]

28. Pankaj, P.; Rajiv, R.S.; Ojasvi. Assessment of legislation and practices for the sustainable management of waste electrical and electronic equipment in India. Renew. Sust. Energ. Rev. 2017, 78, 220-232. [CrossRef]

29. Aznar-Sánchez, J.A.; García-Gómez, J.J.; Velasco-Muñoz, J.F.; Carretero-Gómez, A. Mining Waste and Its Sustainable Management: Advances in Worldwide Research. Minerals 2018, 8, 284. [CrossRef]

30. Alloway, B.J. Heavy Metals in Soils; Blackie: Glasgow, UK, 1995; ISBN 0751401986. 
31. Pérez Cebada, J.D. Mining corporations and air pollution science before the Age of Ecology. Ecol. Econ. 2016, 123, 77-83. [CrossRef]

32. Lundgren, K. The Global Impact of E-Waste: Addressing the Challenge; International Labour Office: Geneva, Switzerland, 2012.

33. Magalini, F.; Kuehr, R.; Baldé, C.P. eWaste in Latin America: Statistical Analysis and Public Policy Recommendations. United Nations University. Institute for the Advanced Study of Sustainability. 2015. Available online: https:/ / www.gsma.com/publicpolicy/ewaste-latin-america-statistical-analysis-policyrecommendations (accessed on 15 March 2018).

34. Robinson, B.H. E-waste: An assessment of global production and environmental impacts. Sci. Total Environ. 2009, 408, 183-191. [CrossRef] [PubMed]

35. Graedel, T.E.; Erdmann, L. Will metal scarcity impede routine industrial use? MRS Bulletin 2012, 37, 325-331. [CrossRef]

36. Kajikawa, Y.; Yoshikawa, J.; Takeda, Y.; Matsushima, K. Tracking emerging technologies in energy research: Toward a roadmap for sustainable energy. Technol. Forecast. Soc. Chang. 2008, 75, 771-782. [CrossRef]

37. Perea-Moreno, A.J.; Perea-Moreno, M.A.; Hernández-Escobedo, Q.; Manzano-Agugliaro, F. Towards forest sustainability in Mediterranean countries using biomass as fuel for heating. J. Clean Prod. 2017, 156, 624-634. [CrossRef]

38. Velasco-Muñoz, J.F.; Aznar-Sánchez, J.A.; Belmonte-Ureño, L.J.; Román-Sánchez, I.M. Sustainable water use in agriculture: A review of worldwide research. Sustainability 2018, 10, 1084. [CrossRef]

39. Corder, G.D. Insights from case studies into sustainable design approaches in the minerals industry. Miner. Eng. 2015, 76, 47-57. [CrossRef]

40. Barbosa-Reis-Monteiro, N.; Machado-Moita-Neto, J.; Aparecida-da Silva, E. Bibliometric study of the crushed stone mining sector. Miner. Process Extr. Metall. Rev. 2018, 39, 235-249. [CrossRef]

41. Rodrigues-Vaz, C.; Shoeninger-Rauen, T.R.; Rojas-Lezana, A.G. Sustainability and innovation in the automotive sector: A structured content analysis. Sustainability 2017, 9, 880. [CrossRef]

42. Albort-Morant, G.; Henseler, J.; Leal-Millán, A.; Cepeda-Carrión, G. Mapping the field: A bibliometric analysis of green innovation. Sustainability 2017, 9, 1011. [CrossRef]

43. Uriona-Maldonado, M.; Silva-Santos, J.L.; Santos, R.N.M. Inovação e Conhecimento Organizacional: Um mapeamento bibliométrico das publicações cientificas até 2009. In Proceedings of the XXXIV Encontro ANPAD, Rio de Janeiro, Brazil, 25-29 October 2010.

44. Duque-Oliva, E.J.; Cervera Taulet, A.; Rodríguez-Romero, C. A bibliometric analysis of models measuring the concept of perceived quality in providing internet service. Innovar. Rev. Cienc. AD 2006, 16, 223-243.

45. Durieux, V.; Gevenois, P.A. Bibliometric indicators: Quality measurements of scientific publication 1. Radiology 2010, 255, 342-351. [CrossRef] [PubMed]

46. Li, Q.; Wei, W.; Xiong, N.; Feng, D.; Ye, X.; Jiang, Y. Social media research, human behavior, and sustainable society. Sustainability 2017, 9, 384. [CrossRef]

47. Yarime, M.; Takeda, Y.; Kajikawa, Y. Towards institutional analysis of sustainability science: A quantitative examination of the patterns of research collaboration. Sustain. Sci. 2010, 5, 115-125. [CrossRef]

48. Ferenhof, H.A.; Vignochi, L.; Selig, P.M.; Lezana, Á.G.R.; Campos, L.M. Environmental management systems in small and medium-sized enterprises: An analysis and systematic review. J. Clean. Prod. 2014, 74, 44-53. [CrossRef]

49. Kim, J.; Lee, S.; Shim, W.; Kang, J. A mapping of marine biodiversity research trends and collaboration in the East Asia Region from 1996-2015. Sustainability 2016, 8, 1075. [CrossRef]

50. Aznar-Sánchez, J.A.; Belmonte-Ureña, L.J.; López-Serrano, M.J.; Velasco-Muñoz, J.F. Forest Ecosystem Services: An Analysis of Worldwide Research. Forests 2018, 9, 453. [CrossRef]

51. Aznar-Sánchez, J.A.; Belmonte-Ureña, L.J.; Velasco-Muñoz, J.F.; Manzano-Agugliaro, F. Economic analysis of sustainable water use: A review of worldwide research. J. Clean. Prod. 2018, 198, 1120-1132. [CrossRef]

52. Padilla, F.M.; Gallardo, M.; Manzano-Agugliaro, F. Global trends in nitrate leaching research in the 1960-2017 period. Sci. Total Environ. 2018, 643, 400-413. [CrossRef] [PubMed]

53. Gusmão-Caiado, R.G.; de Freitas-Dias, R.; Veiga-Mattos, L.; Gonçalves-Quelhas, O.L.; Leal-Filho, W. Towards sustainable development through the perspective of eco-efficiency-A systematic literature review. J. Clean. Prod. 2017, 165, 890-904. [CrossRef] 
54. Van Eck, N.J.; Waltman, L. Software survey: VOSviewer, a computer program for bibliometric mapping. Scientometrics 2010, 84, 523-538. [CrossRef] [PubMed]

55. Velasco-Muñoz, J.F.; Aznar-Sánchez, J.A.; Belmonte-Ureño, L.J.; López-Serrano, M.J. Advances in water use efficiency in agriculture: A bibliometric analysis. Water 2018, 10, 377. [CrossRef]

56. Kajikawa, Y. Research core and framework of sustainability science. Sustain. Sci. 2008, 3, 215. [CrossRef]

57. Galdeano-Gómez, E.; Aznar-Sánchez, J.A.; Pérez-Mesa, J.C.; Piedra-Muñoz, L. Exploring synergies among agricultural sustainability dimensions: An empirical study on farming system in Almería (Southeast Spain). Ecol. Econ. 2017, 140, 99-109. [CrossRef]

58. Schoolman, E.D.; Guest, J.S.; Bush, K.F.; Bell, A.R. How interdisciplinary is sustainability research? Analyzing the structure of an emerging scientific field. Sustain. Sci. 2012, 7, 67. [CrossRef]

59. Mao, G.; Shi, T.; Zhang, S.; Crittenden, J.; Guo, S.; Du, H. Bibliometric analysis of insights into soil remediation. J. Soils Sediments 2018, 18, 2520. [CrossRef]

60. Zhang, C.; Tu, X. The effect of global oil price shocks on China's metal markets. Energy Policy 2016, 90, 131-139. [CrossRef]

61. Milanez, D.H.; de Oliveira, B.S.; Noyons, E.C.M.; Faria, L.I.; Botta, W.J. Assessing Collaboration and Knowledge Flow on Coatings of Metallic Glasses Obtained From Thermal Spraying Processes Using Bibliometrics and Science Mapping. Mat. Res. 2017, 20, 71-80. [CrossRef]

62. Sarukhán, J.; Whyte, A. (Eds.) Millennnium Ecosystem Assessment (MA)—Ecosystems and Human Well-Being; Biodiversity Synthesis World Resources Institute: Washington, DC, USA, 2005.

(C) 2018 by the authors. Licensee MDPI, Basel, Switzerland. This article is an open access article distributed under the terms and conditions of the Creative Commons Attribution (CC BY) license (http:/ / creativecommons.org/licenses/by/4.0/). 